\title{
SUDIRMAN ONLINE TRANSPORT HUB
}

\author{
Abi Rafi Pratama ${ }^{1)}$, Nina Carina ${ }^{2)}$ \\ 1)Program Studi S1 Arsitektur, Fakultas Teknik, Universitas Tarumanagara, a3i.rafip@gmail.com \\ 2) Program Studi S1 Arsitektur, Fakultas Teknik, Universitas Tarumanagara, ninac@ft.untar.ac.id
}

\begin{abstract}
Abstrak
Kemajuan sistem Transportasi berjalan beriringan dengan kemajuan Teknologi. Kemudahan kebutuhan akan transpotasi publik dapat dengan mudah di akses melalui smartphone, dimanapun, dan kapanpun sehingga memunculkan istilah Transportasi Online. Transportasi online adalah pelayanan jasa transportasi yang berbasis internet dalam setiap kegiatan transaksinya,mulai dari pemesanan, pemantauan jalur, pembayaran dan penilaian terhadap pelayanan jasa itu sendiri. Dampak dari kemajuan Transportasi publik berbasis online dapat bersifat positif maupun negatif. Dampak positifnya adalah kemudahan dalam mengakses transportasi publik dimana pun dan kapan pun. Dampak Positif lain dari Transportasi online adalah tingkat kenyamanan yang cukup baik dibanding dengan transportasi publik konvensional dalam hal personal tracking, sehingga mampu membantu pengguna dalam berpindah tempat dengan cepat. Dampak negatif dalam kemajuan transportasi publik berbasis online adalah kemacetan yang disebabkan penumpukan kendaraan online, pergesekan antara pengemudi transportasi online dengan pengemudi Transportasi konvensional dan penggunaan bahu jalan yang dijadikan titik-titik area menunggu customer yang menyebabkan volume jalan menjadi terbatas dan membuat kemacetan. Untuk itu Sudirman Online Transport Hub hadir untuk mengatur ruang atau titik-titik berkumpul mereka supaya lebih tertata dan lebih teratur pergerakan dan pemantauannya. Fasilitas (Transport hub) untuk transportasi publik berbasis online ini merupakan sebuah proyek yang dibuat agar transportasi khususnya yang berbasis online tidak lagi menggunakan bahu jalan untuk area berkumpul,area menunggu pengguna dan sebagainya, sehingga antara pengemudi dengan pengguna sama-sama memiliki fasilitas yang layak untuk menunggu, menjemput dan juga beristirahat. Fasilitas ini juga dilengkapi banyak fungsi pendukung lain yang dibuat khusus supaya dapat diakses menggunakan aplikasi yang dirancang khusus untuk proyek ini.
\end{abstract}

Kata kunci: berpindah tempat dengan cepat; Fasilitas Transport hub; Transportasi online; kemacetan.

\begin{abstract}
The advancement of the Transportation system goes hand in hand with the advancement of Technology. The ease of the need for public transportation can be easily accessed through smartphones, anywhere, and anytime so as to bring up the term Online Transportation. Online transportation is an internet-based transportation service in every transaction activity, ranging from booking, monitoring lines, payment, and assessment of the service. The impact of the progress of online-based public transportation can be both positive and negative. The positive impact is the ease of accessing public transportation anywhere and anytime. Another positive impact of online transportation is a fairly good level of comfort compared to conventional public transportation in terms of personal tracking, to help users in moving quickly. The negative impacts in the advancement of online-based public transportation are congestion caused by the buildup of online vehicles, friction between online pengemudi Transportasi onlines and conventional pengemudi Transportasi onlines and the use of the shoulder of the road that is used as points of customer waiting areas that cause the volume of roads to be limited and create congestion. Therefore, Sudirman Online Transportation Hub is present to organize their space or gathering points to be more organized and more organized movement and monitoring. Transport hub facility for online-based public transportation is a project created so that transportation, especially online-based ones no longer use the shoulder of the road for the gathering area, user waiting area and so on, so that the pengemudi Transportasi online and the user both have decent facilities to wait, pick up, and also rest. The facility also features many other supporting functions that are specially created so that they can be accessed using applications specifically designed for the project.
\end{abstract}

Keywords: congestion; moving quickly; Transport hub facility; Online transportation 


\section{PENDAHULUAN}

\section{Latar Belakang}

Pada era digital ini hadirnya transportasi online menjawab kebutuhan masyarakat agar segala sesuatunya dapat dilakukan secara praktis. Calon penumpang tidak perlu lagi menghampiri pangkalan ojek atau berdiri ditepi jalan untuk memberhentikan kendaraan umum atau bahkan terlibat proses tawar menawar harga untuk menempuh sebuah perjalanan yang akan dituju.

Ojek online, merupakan transportasi lanjutan dari transportasi utama seperti KRL,MRT ataupun busway, dimana transportasi ini bisa dikatakan penyambung perpindahan orang dari tempat $A$ ketempat $B$, yang dimana mungkin area itu tidak dapat diakses menggunakan moda transportasi besar utama. Ojek online sendiri memiliki 2 pilihan transportasi, mulai dari roda dua dan hingga roda 4. Disituasi sekarang ini yang dimana sedang menyebarnya virus covid-19, pengguna transportasi online meningkat pesat karena dinilai lebih memiliki personal tracking dibandingkan transportasi masal lainnya. Hal ini yang membuat semakin banyak pengemudi Transportasi online yang ada dijalanan. Salah satu kawasan yang cukup banyak penggunanya adalah kawasan Sudirman.

Jakarta tidak lagi mengandalkan hanya angkutan umum online saja tetapi mulai merambah kearah kendaraan online lainya seperti bike sharing, skuter sharing ataupun motor listrik yang bisa di sewa dengan sistem online. Penggunaan transportasi online saat ini meningkat pesat, dapat dilihat dengan semakin banyaknya pengemudi Transportasi online yang dapat ditemui disepanjang jalan. Keberadaan transportasi berbasis online ini tidak hanya memberikan dampak positif tetapi juga dampak negatif bagi sebuah kawasan, terutama dalam penyempitan volume jalan raya akibat keberadaan mereka.

\section{Rumusan Permasalahan}

Permasalahan dikawasan Sudirman terutama dititik-titik pemberhentian transportasi publik seperti $\mathrm{KRL}$, busway, MRT dan sebagainya adalah kurangnya kawasan ini dalam menyambut moda transportasi umum berbasis online. Ketidak siapan titik- titik tersebut teridentifikasi dari :
a. Kurangnya area menunggu penumpang ataupun pengemudi yang dapat menunjang mobilitas penggunanya
b. Kurangnya efisiensi waktu tempuh akibat terlalu jauh dengan pengemudi sehingga waktu tempuh semakin lama
c. Penggunaan bahu jalan sebagai titik- titik area menunggu yang menyebabkan berkurangnya lebar jalan sehingga membuat kemacetan
d. Faktor lainnya adalah area tunggu yang ada sekarang ini malah mengorbakan ruang publik dan ruang terbuka hijau yang ada

\section{Tujuan proyek}

Berdasarkan rumusan masalah diatas maka tujuan projek ini adalah:
a. Menciptakan wadah yang mampu menunjang aktivitas pergerakan terhadap transportasi umum berbasis online.
b. Membuat sebuah Fasilitas yang dapat mengurangi dampak kemacetan akibat penyalahgunaan ruang jalan sebagai ruang parkir transportasi berbasis online.
c. Mengefektifkan dan mempersingkat waktu dan jarak tempuh yang dibutuhkan, sehingga efisiensi waktu tempuh semakin pendek.
d. Dapat mewujudkan bangunan yang mandiri dalam segi sumber energy yang dibutuhkan

\section{KAJIAN LITERATUR}

Dalam melakukan perancangan penulis berorientasi kepada teori yang sudah ada untuk memahami lebih dalam makna dari sebuah Ekologi. Teori yang di ambil Pengertian dasar Ekologi, Pengertian Transit Oriented Development, Pengertian Transport Hub, Pengertian Transportasi Online. 


\section{Pengertian Dasar Ekologi}

Pada dasarnya Ekologi didefinisikan sebagai ilmu tentang hubungan timbal balik antara makhluk hidup dengan lingkungannya. Istilah ekologi pertama kali diperkenalkan oleh Haeckel, seorang ahli biologi, pada pertengahan dasawarsa 1860-an. Ekologi berasal dari bahasa Yunani, oikos yang berarti rumah dan logos yang berarti ilmu, sehingga secara harafiah ekologi berarti ilmu tentang rumah tangga makhluk hidup (KRISTANTO, Ir.Philip. 2002.)

Ekologi merupakan sebuah ilmu yang mempelajari sebuah ekosistem, yang mana ekosistem itu dibagi menjadi 2 komponen yaitu: Komponen biotik dan Komponen abiotik. Komponen biotik merupakan komponen ekosistem yang terdiri atas makhluk hidup yang akan menempati peran sebagai:

- Produsen, biasanya ditempati oleh makhluk hidup yang dapat melakukan fotosintesis atau organisme autotrof.

- Konsumen, biasanya ditempati oleh organisme yang memakan makhluk hidup lainnya, misalnya hewan herbivore, hewan karnivora atau hewan omnivora.

- Detritivor atau pemakan sampah, biasanya ditempati oleh hewan yang memakan sisa sampah makhluk hidup yang telah mati, contohnya yaitu rayap, cacing tanah, keluwing dan teripang.

- Dekomposer atau pengurai, biasanya ditempati oleh makhluk hidup yang menguraikan zat organik menjadi zat anorganik, contohnya yaitu bakteri dan jamur.

Komponen abiotik merupakan komponen penyusun ekosistem yang terdiri dari benda-benda tak hidup. Secara terperinci, komponen abiotik merupakan keadaan fisik dan kimia disekitar organisme yang menjadi medium dan substrat untuk menunjang berlangsungnya kehidupan organisme tersebut. Beberapa contoh komponen abiotik antara lain: air, udara, cahaya matahari, tanah, topografi, iklim.

Ilmu ekologi pada awalnya merupakan suatu pengetahuan umum dan hanya mempelajari hubungan lingkungan secara individual atas dasar fisiologi. Pada waktu itu para cendekiawan, khususnya dari kalangan ilmu alam, kurang menaruh perhatian pada berbagai ilmu yang sifatnya umum, tetapi orang lebih banyak mengarahkan perkembangan ilmu-ilmu ke arah spesialisasi. Walaupun perhatian orang terhadap ilmu ekologi jika dibandingkan dengan ilmu lain, terutama ekonomi dan politik kurang memadai, namun ekologi terus berkembang. Sebagai bukti bahwa ilmu ekologi dapat terus berkembang dan melebarkan sayapnya ke bidang-bidang lain seperti botani, dan zoologi. Belakangan ini kebijakan pemerintah dan berbagai organisasi lain dalam "perlindungan alam dan lingkungan permukiman" serta " pemeliharaan dan pelestarian lingkungan" didasarkan atas hasil penelitian dan ajaran ilmu ekologi.

Pengertian TOD (Transit Oriented Development)

Pengertian Transit Oriented Development Menurut Peter Calthrope dalam Transit-Oriented Development Design Guidelines tahun 1992 pengertian dari Transit-Oriented Development (TOD) adalah "sebuah komunitas bangunan mix-used yang mendorong 17 masyarakat untuk tinggal dan beraktifitas di area kawasan yang memiliki fasilitas transportasi umum dan menurunkan kebiasaan masyarakat mengendarai mobil pribadi".

Pengembangan TOD harus berupa bangunan mix-used atau bangunan yang memiliki banyak fungsi. Stasiun kereta, terminal bus, halte bus, atau titik transportasi kota lainnya menjadi pusat kegiatan dengan taraf aktifitas tinggi yang akan semakin berkurang ketika semakin menjauhi titik transportasi kota yang ada. Pengembangan Transit Oriented Development memiliki radius optimal 400 sampai 800 meter dari tempat transit transportasi kota (stasiun kereta, terminal bus, halte bus, dll) menjadi satu pusat kegiatan yang menarik. Dengan memanfaatkan transportasi umum, masyarakat akan diarahkan untuk berjalan kaki atau menggunakan sepeda, sehingga penerapan konsep TOD akan sangat berpengaruh pada pedestrian pejalan kaki dan tersedianya lahan parkir kendaraan khususnya parkir sepeda. Berjalan kaki/menggunakan sepeda mengelilingi kawasan dapat mengurangi intensitas dari kendaraan pribadi, ketika kendaraan pribadi berkurang akan mengurangi kemacetan dan penggunaan bahan bakar, sehingga akan berdampak pada pengurangan polusi dari kendaraan di sekitar kawasan dan menciptakan situasi yang ramah lingkungan. 


\section{Pengertian Transport Hub}

Transport Hub adalah pusat pertukaran penumpang dari satu moda transportasi ke moda transportasi lainnya. Transportasi adalah pengangkutan orang atau barang oleh berbagai jenis kendaraan sesuai dengan kemajuan teknologi (KBBI, 2019). Hub berarti "A central airport or other transport facility from which many services operate" (Oxford Dictionary, 2019), atau dapat diartikan sebagai bandara sentral atau fasilitas transportasi lainnya dengan banyak layanan yang beroperasi. Transport hub menyediakan fasilitas yang menunjang Kawasan campuran dengan kepadatan yang tinggi sehingga sehingga dapat melengkapi dalam skala, desain dan konteks, dan dirancang untuk mendukung layanan transit. Berdasarkan klasifikasi Transportation transit hub dalam sebuah daerah dalam sistem transportasi umum yang didasarkan dalam jumlah penumpang dan skala kontruksinya di bedakan menjadi tiga kelompok yaitu:

- Local public transport hub, adalah tempat angkutan umum dengan tingkat lalu lintas penumpang yang minimum yang berada di daerah jaringan lokal.

- Municipal Public transport hub, adalah pusat multi moda dengan tingkat menengah atau tinggi penumpang. Transit hub ini melayani antar wilayah dan wilayah lokal.

- City, regional and other high level public transport transit hub, adalah tempat yang memiliki tingkat penumpang yang sangat tinggi. Transit hub ini berada di perbatasan yang menghubungkan antar kota dan menyediakan semua moda transportasi umum internal/wilayah.

Menurut MODex terdapat Empat kunci untuk pengembangan sistem transit pada transport hub yaitu:

- Transit hub Conentivity: Menjadikan transport hub memiliki kualitas dan kuantitas dari aksesbilitas transit, dengan cara memfasilitasi terhubungnya pemberhentian angkutan umum dengan fasilitas di sekitarnya. Serta memberikan kenyamanan pada penggunan transportasi umum maupun masyarakat.

- Urban Environment: Membentuk perkotaan dengan intensitas kepadatan yang tinggi dan mengembangkan Kawasan campuran pada sekitar transport hub.

- Social Placemaking: Social placemaking ini berkontribusi pada penempatan lingkungan perkotaan yang dinamis dan multimodal

- Economic Development: Transport hub mampu meningkatkan aktivitas ekonomi dan nilai property di lingkungan perkotaan

Dengan demikian, Transport Hub dalam penulisan ini dapat diartikan sebagai ruang penghubung antar stasiun sentral yang mengakomodasi pertukaran penumpang dari berbagai moda transportasi dengan fasilitas pendukung alur sirkulasi penumpang.

\section{Pengertian Transportasi Online}

Pengertian transportasi online adalah pelayanan jasa transportasi yang berbasis internet dalam setap kegiatan transaksinya, mulai dari pemesanan, pemantauan jalur, pembayaran dan penilaian terhadap pelayanan jasa itu sendiri. Transportasi online adalah salah satu bentuk dari penyelenggara lalu lintas dan angkutan jalan yang berjalan dengan mengikuti serta memanfaatkan perkembangan ilmu pengetahuan (teknologi).(adinda 2016)

Jasa transportasi online merupakan jasa transportasi yang memanfaatkan kemajuan teknologi. Teknologi diciptakan tujuannya untuk mempermudah segala aktivitas-aktivitas manusia yang dilakukan sehari-hari. Transportasi online merupakan transportasi yang berbasis suatu aplikasi tertentu, dimana konsumen memesan suatu sarana transportasi melalui sistem aplikasi di dalam smartphone. Saat konsumen melakukan pemesanan dengan menggunakan aplikasi, detail pemesanan seperti jarak tempuh, harga, identitas pengemudi, lama waktu pengemudi tiba kelokasi konsumen, serta data perusahaan pengelolanya sudah langsung tersaji pada layar smartphone konsumen. Seluruh identitas pengemudi sudah diketahui secara pasti karenan perusahaan pengelola telah melakukan proses verifikasi terlebih dahulu sebelum melakukan kerja sama kemitraan dengan pengemudi. 


\section{Hubungan kemajuan Transportasi dengan dampak Ekologi kota}

Dampak bagi lingkungan, perencanaan sistem transportasi yang kurang matang bisa menimbulkan berbagai permasalahan, diantaranya kemacetan dan tingginya kadar polutan udara akibat berbagai pencemaran dari asap kendaraan bermotor. Dampak yang dirasakan akibat menurunnya kualitas udara perkotaan adalah adanya pemanasan kota akibat perubahan iklim, penipisan lapisan ozon secara regional, dan menurunnya kualitas kesehatan masyarakat yang ditandai terjadinya infeksi saluran pencernaan, timbulnya penyakit pernapasan, adanya $\mathrm{Pb}$ (timbal) dalam darah, dan menurunnya kualitas air bila terjadi hujan (hujan asam).

Berdasarkan data Badan Pusat Statistik (BPS) jumlah kendaraan bermotor di Indonesia pada tahun 2017 mencapai 138,56 juta unit. Jumlah tersebut terbagi menjadi mobil penumpang sebanyak 15,49 juta unit; mobil bus sebanyak 2,51 juta unit; mobil barang sebanyak 7,52 juta unit; dan sepeda motor sebanyak 113,03 juta unit.

\section{METODE}

Dalam proses perancangan ini terdapat, beberapa metode yang dilakukan perancang untuk mengumpulkan data, yaitu, survey, dan dokumentasi. Data ini sendiri dibagi menjadi dua yaitu data primer dan data sekunder. Data primer adalah data yang didapat secara langsung dari sumber asli atau tidak memiliki perantara sedangkan data sekunder adalah data yang diperoleh perancang secara tidak langsung yaitu melalui media perantara.

\section{Pengumpulan Data}

- Pengumpulan data primer

Pada survey ini dilakukan pengamatan secara individual terhadap mobilitas pergerakan yang ada dikawasan tersebut.

- Pengumpulan data sekunder Dalam penulisan ini data sekunder didapat dari Peraturan tataruang dan guna lahan Daerah Kota jakarta tahun 2020. Berita-berita terkait topik permasalahan yang akan di ambil, Studi preseden Untuk mengetahui fungsi-fungsi yang diperlukan dalam mendesain Layanan Transit Oriented development (TOD dan Transport Hub)

- Studi literatur Untuk mengetahui makna Ekologi bagi manusia , Ekologi bagi sebuah kota dan mencari tahu masalah yang sedang terjadi saat ini, mempelajari tentang Transport Hub, memperlajari tantang Transit Oriented Development dan mempelajari tentang Transportasi Online dan keterkaitannya dengan sebuah Kota.

\section{Pengolahan Data}

Berbagai macam data dari berbagai sumber yang sudah dikumpulkan dan distudi untuk mendapatkan dasar dari perancangan proyek Transport Hub

\section{Metode Analisis}

Analisis merupakan proses pengamatan yang berdasarkan kriteria tertentu sehingga dapat melahirkan solusi yang bersifat ilmiah. Beberapa analisis yang dilakukan dalam perancangan arsitektur, diantaranya;

- Analisis tapak, yang membahas mengenai masalah dan kondisi eksisting tapak.

- Analisis fungsi bangunan, membahas baik fungsi utama dan penunjang bangunan.

- Analisis sirkulasi, yang membahas sirkulasi pengguna dalam bangunan

- Analisis bentuk, yang membahas bentuk fisik bangunan dengan konsep yang terpilih

- Analisis konsep penerapan pada desain 


\section{DISKUSI DAN HASIL}

Ide dalam rancangan proyek ini timbul akibat permasalahan pada Transportasi umum berbasis online dimana Fasilitas ruang tunggu untuk pengemudi Transportasi online ataupun pengguna tidak memadai atau bahkan tidak ada di daerah TOD Sudirman, sehingga perancang ingin membuat desain berupa Transport Hub yang dapat dinikmati semua kalangan. Proyek tidak hanya untuk aktivitas pergerakan perpindahan antar moda Transportasi tetapi juga menyediakan ruang interaksi masyarakat yang menekankan pada ruang terbuka hijau. semua fungsi bangunan didukung teknologi digital dapat diakses dengan mudah melalui sebuah aplikasi.

Rancangan program pada tapak dibagi menjadi dua yaitu program utama dan program penunjang. Program utama berfokus pada permasalahan bagi kenyamanan sehingga pengemudi Transportasi online yang dapat menjadikan area tunggu customer. Bangunan dilengkapi program penunjang yang mampu mendukung program utama seperti co-working space, retail store, food area, fresh market dan sebagainya. Selanjutnya semua program yang ada di bangunan ini hanya dapat diakses dengan sebuah sistem. Sistem ini berupa aplikasi yang memuat semua fungsi atau layanan yang ada didalam bangunan sehingga memudahkan pengguna dalam mengakses fungsi yang ada dibangunan dengan mudah.

Rancangan bangunan tidak terlepas dari rancangan aplikasi digital, Aplikasi digital ini memungkinkan semua jenis aplikasi pemesanan transportasi online terintegrasi langsung sehingga :

- Posisi pengemudi lebih dekat dengan pemesan

- Pemesan tidak terbatas pada 1 aplikasi saja, sehingga waktu lamanya pemesanan jauh lebih efektif

- Memenuhi kebutuhan yang dapat dilakukan dimana saja dan kapan saja tanpa terlalu lama berinteraksi di ruang publik

- Efisiensi waktu tempuh samakin cepat

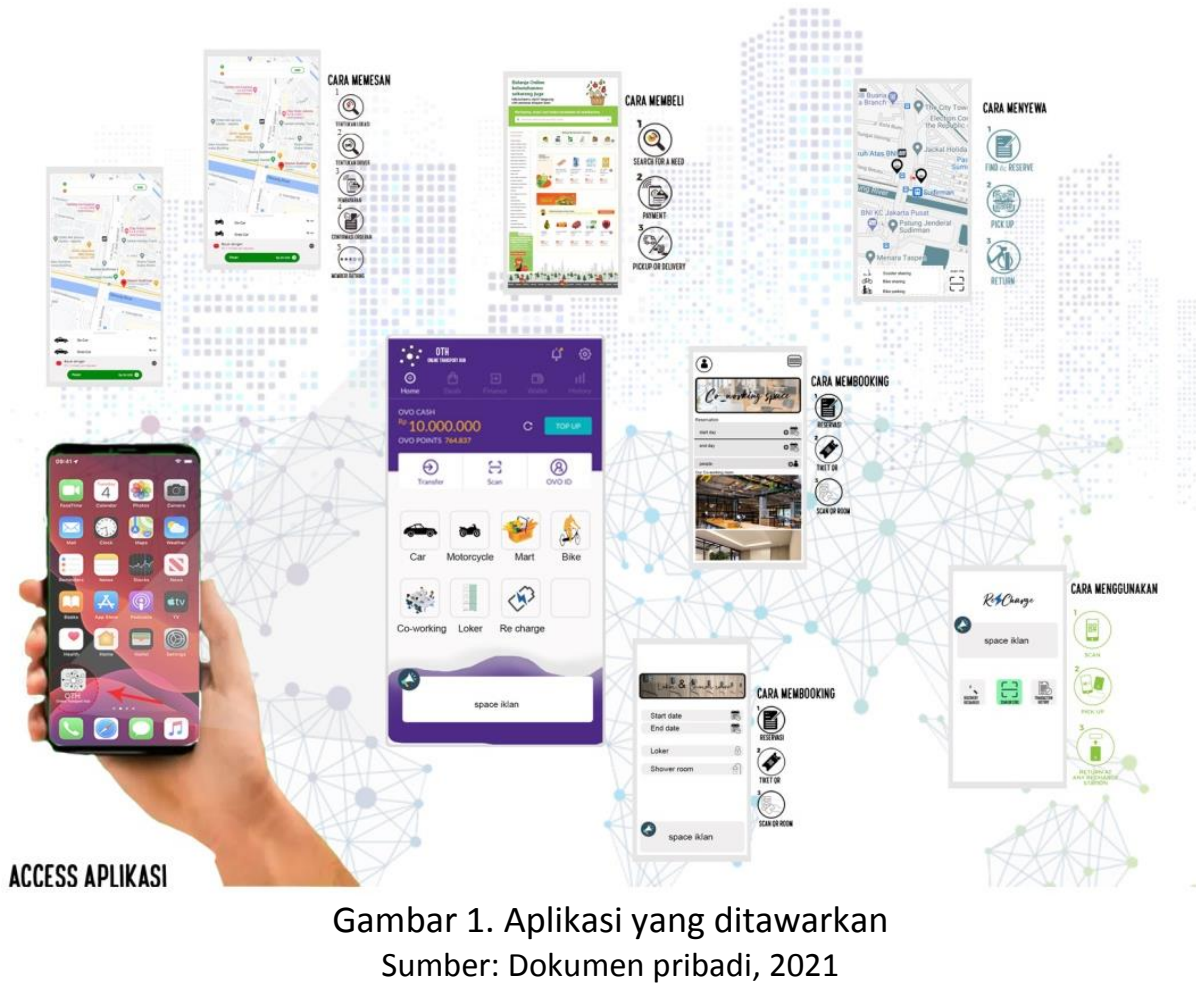

Aplikasi ini merespon terhadap kemajuan teknologi yang berkembang saat ini, dimana saat ini segala aktifitas sudah dapat dikendalikan dengan smartphone. Aplikasi ini khusus di rancang hanya untuk bangunan ini saja, karena diharapkan bangunan ini dan fungsi didalamnya menjadikan bangunan yang High Technology dalam konsep pemasaran dan mengaksesnya. Dimasa ini dan masa yang akan datang nantinya, segala macam hal mengenai kebutuhan dapat diatur dan diakses menggunakan smartphone atau teknologi, sehinga efisiensi waktu yang di hasilkan dapat lebih maksimal. 
Proses pembentukan massa bangunan memperhatikan arah pergeseran matahari sehingga dapat memaksimalkan bukaan yang dihasilkan. Selain itu setiap lantai dalam gubahan masa tidak sama arah hadapnya, sehingga setiap lantai memiliki view arah hadap tersendiri yang dapat menciptakan pengelihatan terhadap lingkungan sekitar tapak dari sudut yang berbeda-beda.

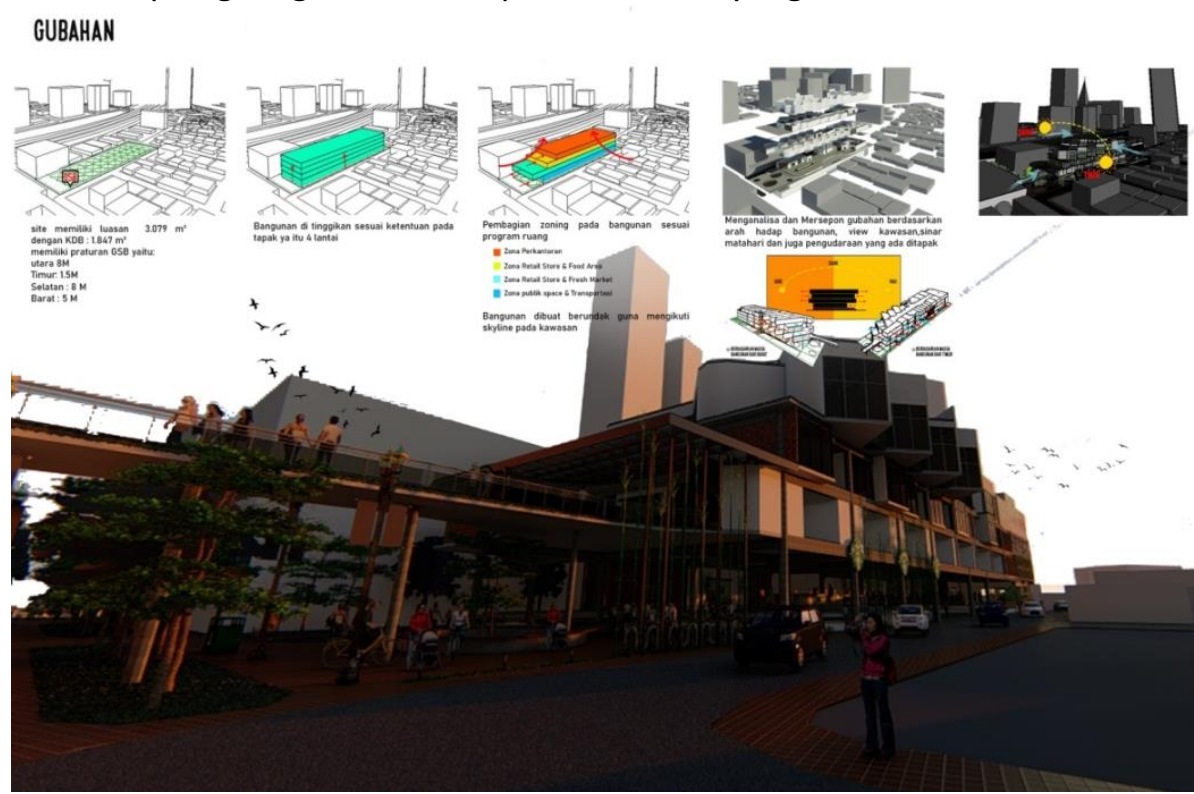

Gambar 2: Proses Gubahan massa Sumber : Dokumentasi Pribadi, 2021

Selain arah hadap, pergerakan matahari dan pergerakan udara juga mempengaruhi dalam bentuk bangunan. Bangunan juga memiliki fitur yang disesuaikan terhadap tapak yang dilakukan guna merespon faktor -faktor lain dalam pembentuk seperti akses, support area dan sebagainya. Gambar dibawah ini merupakan penjabaran fitur-fitur yang ada kedalam bangunan.

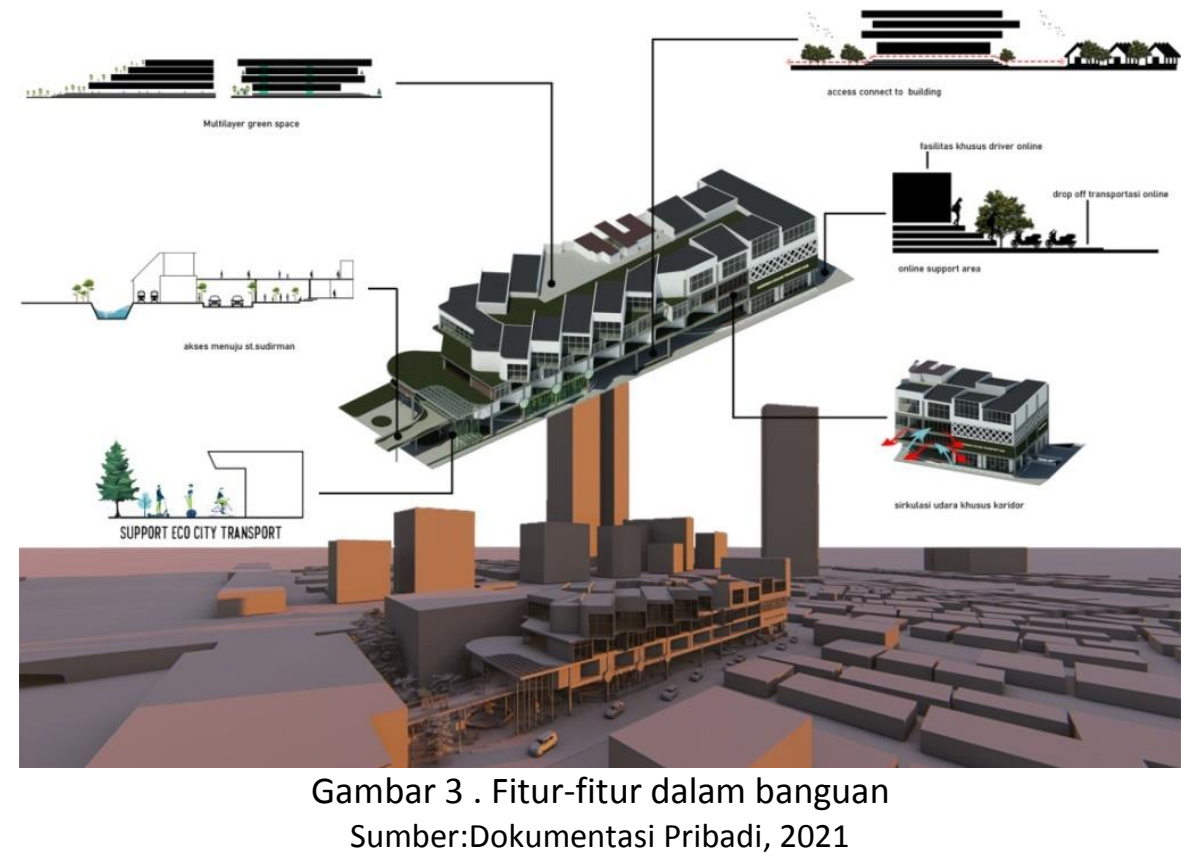

Konsep dalam bangunan dapat tercipta dari analisis yang dilakukan pada site, akitvitas, kebutuhan ruang dan faktor lainnya sehingga dapat menciptakan proyek yang dapat mewadahi aktivitas pergerakan antar moda transportasi di Kawasan TOD Dukuh Atas. 


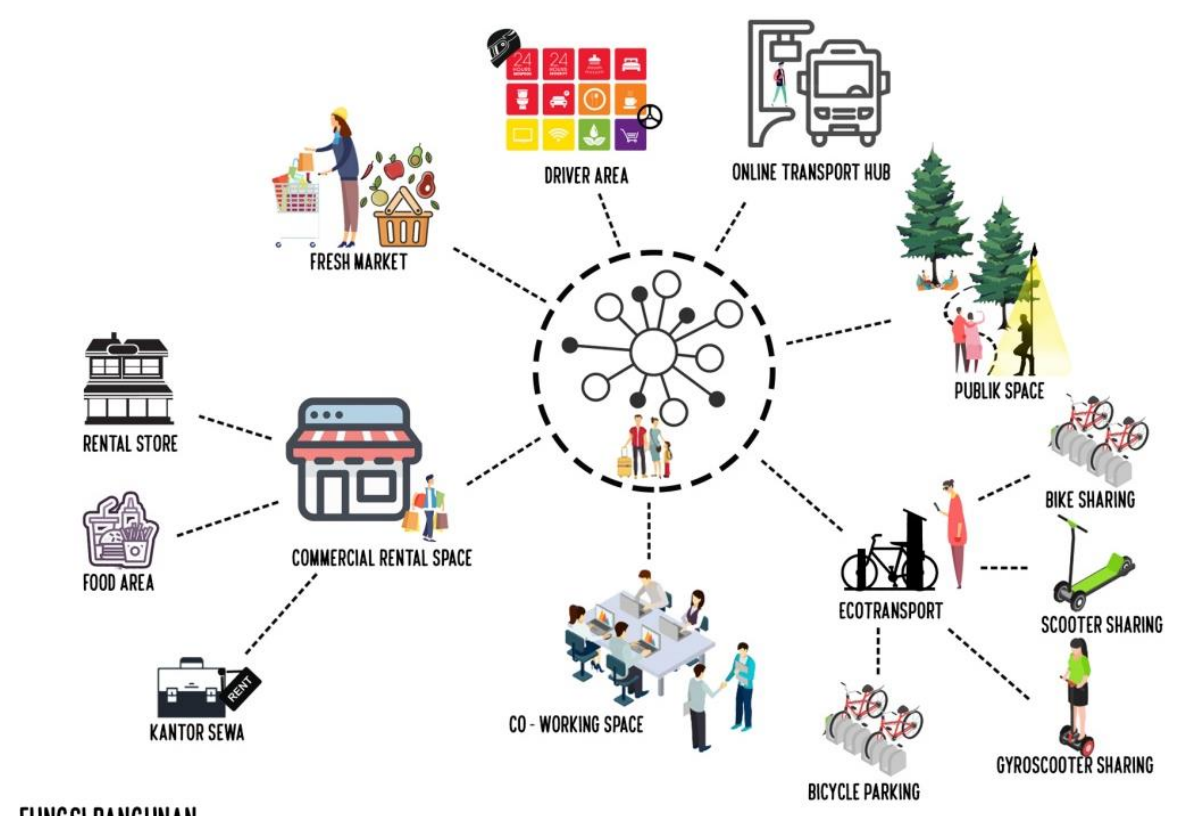

FUNGSI BANGUNAN

Gambar 4 . Program yang ditawarkan

Sumber:Dokumentasi Pribadi, 2021

Dengan luas tapak kurang lebih $3.079 \mathrm{~m}^{2}$. program ruang didalam bangunan ini adalah:

- Online Transport Hub

Area tunggu yang dikhusukan untuk melayani penggunaan transportasi publik berbasis online

- Fresh Market

Area ini merupakan fungsi yang menjual segala macam kebutuhan sehari-hari dalam hal pangan

- Public space

Area yang dikhusukanj untuk interaksi sosial di kawasan tersebut dan juga dapat dijadikan sebagai communal space

\section{- EcoTransport}

Fungsi ini merupakan fungsi yang mendukung pergerakan teknologi dalam hal transportasi, fungsi ini menyediakan dan menyewakan transportasi yang lebih ramah lingkungan seperti bike sharing, scooter sharing, bicycle parking untuk yang membawa sepeda dan sebagainya.

- Co-working Space

Area yang dibuat untuk menunjang pengguna dikawasan Sudirman yang didominasi oleh pekerja kantor, sehingga pengunjung juga dapat menyelesaikan pekerjaannya selagi berpindah antar moda transportasi.

- Comercial space

Area ini merupakan area untuk retail space, area food and beverage dan juga kantor sewa

- Pengemudi Transportasi online Area

Area yang dibuat untuk menujung dan memfasilitasi para pengemudi online yang sedang menunggu dan beristirahat didalamnya.

Karena salah satu fokus utama dari fungsi bangunan ini adalah untuk menfasillitasi transportasi berbasis online maka fungsi-fungsi untuk mendukung area tersebut antara lain sebagai berikut: 


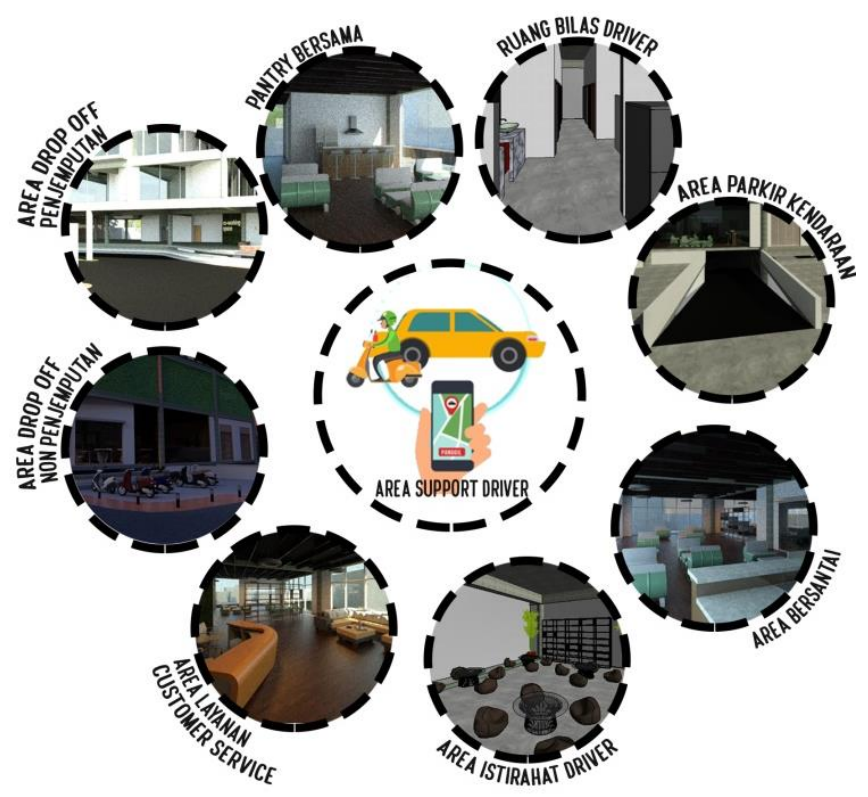

Gambar 5 . Fasilitas untuk Pengemudi Transportasi online Sumber:Dokumentasi Pribadi, 2021

Program utama yang ditawarkan adalah area yang dikhusukan untuk transportasi online mulai dari area penjemputan dan menurunkan customer, parkir khusus Transportasi online hingga area isitirahat dan bersantai khusus pengemudi Transportasi online. Semua fasilitas ini saling berhubungan satu sama lain. Fasilitas-fasilitas yang disediakan nantinya ini didapat berdasarkan hasil pengamatan terhadap hal-hal yang dibutuhkan pengemudi saat mereka menunggu pesanan atau pada saat mereka berada di area dimana pengemudi berkumpul.

\section{KESIMPULAN DAN SARAN}

\section{Kesimpulan}

Sudirman Online Transport Hub berfokus pada sebuah aplikasi yang terkoneksi dan terintegrasi dengan beberapa aplikasi pemesanan transportasi umum, pemesanan makanan, pemesanan bahan kebutuhan sehari-hari yang telah ada sebelumnya. Sistem ini dapat menjawab setidaknya permasalahan ekologi sebuah perkotaan akibat waktu yang terbuang di jalan, serta kemacetan jalan disebabkan penyempitan ruang jalan akibat penggunaan bahu jalan sebagai parkir kendaraan transportasi online. Semakin efisien jarak tempuh makan semakin kecil tingkat kemacetan kendaraan dan semakin rendah juga emisi gas buang yang dihasilikan dari kemacetan kendaraan. Proyek ini juga menjadi Fasilitas pemenuhan kebutuhan bagi para pengemudi Transportasi online nernasis layanan online yang selama ini belum pernah diwadahi dalam sebuah bangunan publik.

Proyek ini memiliki visi untuk mempersiapkan sebuah sistem layanan transportasi online yang terhubung dengan life style di mana segala aktivitas manusia dapat diatur dan dijalankan hanya dengan sebuah smartphone, sehingga efisensi waktu yang dibutuhkan seseorang dalam memenuhi kebutuhannya dan mobilitasnya dapat lebih efektif.

\section{Saran}

Pemikiran dan hasil karya tugas akhir ini masih jauh dari kata sempurna. Karya aristektur merupakan hasil dari pengembangan sebuah ide. Dalam arsitektur, tidak ada karya yang sempurna. Untuk itu, penulis sangat terbuka akan saran dan masukan dari pembaca.

\section{REFERENSI}

Edra S. (2015). Konsep Deep Ecology dalam Pengaturan Hukum Fakultas hukum universitas Bengkulu Hastanto, (2007), Bisnis Tranportasi online :pengertian , Tujuan, manfaat dan Mekanisme.

https://www.hestanto.web.id/bisnis-transportasi-online/ di akses 19 February 2021 Kormondy, E.J. (1969). Concepts of Ecology. Prentice-Hall Inc., New Jersey. 
Persaingan Transportasi Online, https://www.idntimes.com/business/economy/putrianacahya/persaingan-tiga-transportasi-online-terbesar/3 , diakses pada tanggal 19 February 2021

Pengertian, Ruang lingkup Ekologi dan Ekosistem, http://repository.ut.ac.id/4305/1/BIOL4215M1.pdf, diakses pada 08 February 2021

Pengertian Transit Oriented Devlopment, http://library.binus.ac.id/eColls/eThesisdoc/Bab2/2012-201215-AR\%20Bab2001.pdf, di akses pada 10 FEBRUARY 2021

Pengertian Transport Hub http://e-journal.uajy.ac.id/22017/3/TA\%202116104.pdf, diakses pada 11 February 2021

Rengga Ondy Marta dan Baroto Tavip Indrojarwo, M.Si, Desain Shelter Bus Dengan Konsep Berirama Untuk Menekan Permasalahan Antivandalisme dan Tindak Kejahatan Kota Surabaya, Institut Teknologi Sepuluh November,JURNAL SAINS DAN SENI POMITS Vol. 1, No. 1, (2013) 1-6

Resosudarmo, R.S.; K. Kartawinata; A. Soegiarto. (1992). Pengantar ekologi. Penerbit Remaja Rosdakarya. Bandung

Udjianto, P. (2016) ,Dasar- dasar pendekatan -pendekatan dalam Arsitektur 